\title{
Pulmonary hypertension in systemic sclerosis
}

\author{
ERIK TRELL AND CLAS LINDSTRÖM \\ From the Departments of Medicine (Director: Prof. J. Waldenström) and Pathology (Director: Prof. F. Linell), \\ University of Lund, Malmö General Hospital, Malmö, Sweden
}

Pulmonary fibrosis is common in systemic sclerosis, and may lead to cor pulmonale. Changes in the pulmonary arterial system also occur and may cause progressive pulmonary hypertension and right heart failure. A case is reported in detail below, with eight other cases which came to necropsy.

\section{Case report}

A woman born in 1912 (Case 8 in the necropsy series) had an unremarkable family history.

In 1940, she first noted blanching and cyanosis of the fingers on exposure to cold. Since 1960, small, hard, subcutaneous nodules developed at different locations on her body. Early in 1968, progressive effort dypsnoea and anginal chest pains started insidiously, and treatment with digitalis, furosemide, and potassium was instituted. In September, 1968, she was admitted to the Medical Clinic for heart catheterization. Anticoagulants, reserpine, and theophylline were added to her regimen, but her condition gradually deteriorated, with fatigue, dyspnoea at rest, anginal pains, ankle oedema, cyanosis, and syncopal attacks. She died on January 26, 1969.

\footnotetext{
Physical examination

The patient was thin and emaciated. The skin showed marked greyish-brown hyperpigmentation but no teleangiectasia. The joints were normal but the glistening skin of the fingers, hands, and forearms was adherent to the indurated underlying tissue, restricting movement in the finger joints. Atrophy and tapering of the digits were noted, as were hard subcutaneous nodules, particularly over both patellae. Other physical findings included cyanosis, moderate ankle and crural oedema, distended neck-veins and slight hepatomegaly. The breath-sounds were normal. Over the heart, there was a right ventricular lift, and the pulmonic component of the widely split second sound was accentuated. At the apex and in the fourth intercostal space near the left sternal border a grade 2-3/6 pansystolic, low-frequent murmur was present.
}

Consecutive laboratory findings

Arterial $\mathrm{PO}_{2} 72-61 \mathrm{~mm}$. $\mathrm{Hg}$ and $\mathrm{PCO}_{2} 26-29 \mathrm{~mm}$. $\mathrm{Hg}$.

Haemoglobin 17.6-14.5 g. $/ 100 \mathrm{ml}$.

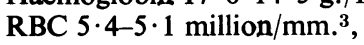

WBC 4,500-8,600/mm. ${ }^{3}$,

Differential count normal.

Platelets $170,000-120,000 / \mathrm{mm}^{3}$

Serum bilirubin $1 \cdot 8-2 \cdot 4 \mathrm{mg} . / 100 \mathrm{ml}$. with a positive direct reaction.

SGPT 35-100 Karmen units; SGOT 19-100 Karmen units; serum alkaline phosphatase normal; serum $\gamma$-glutamyl transpeptidase 127-98 units (normal 15-80); serum lactate dehydrogenase 585 Wroblewski units with slight elevations of the iso-enzyme fractions $\mathrm{LDH}_{1}$ and $\mathrm{LDH}_{2}$ and, less pronounced, $\mathrm{LDH}_{3}$.

Thymol extinction normal.

Agarose gel electrophoresis and quantitative plasma protein determinations showed a slight inflammatory reaction and normal values of IgG, IgA, and IgM. Serum cryoglobulin negative.

Erythrocyte sedimentation rate $2-1 \mathrm{~mm} . / 1 \mathrm{st}$ hour.

Extensive serological tests revealed positive WaalerRose (titre 1/64) and F II A (titre 1/160) reactions, and a weakly positive antinuclear factor reaction (titre $1 / 20$ ). LE-cells were not found.

Detailed coagulation analyses exhibited increased platelet adhesiveness and fibrinolysis inhibitor activity, and decreased vessel-wall fibrinolytic activity, but were otherwise normal.

\section{Further investigations}

Ordinary chest $x$ rays (Fig. 1, opposite) revealed no sign of pulmonary fibrosis. The heart measured 1,060-950 ml. $/ 640-610 \mathrm{ml}$. per $\mathrm{m}^{2}{ }^{2} \mathrm{BSA}$ and indicated right ventricular enlargement.

$X$-ray investigations of the hands and knees (Fig. 2, opposite) exhibited subcutaneous calcifications (Thibiérge-Weissenbach).

Angiocardiography (Fig. 3, overleaf) showed marked right ventricular dilatation and hypertrophy, and an extremely slow contrast passage through the lungs. The pulmonary arteries were dilated centrally, but from the secondary divisions there was a marked narrowing of their calibre.

Spirometry in July and September, 1969, showed ventilatory capacity $83-80$ per cent. of calculated normal 


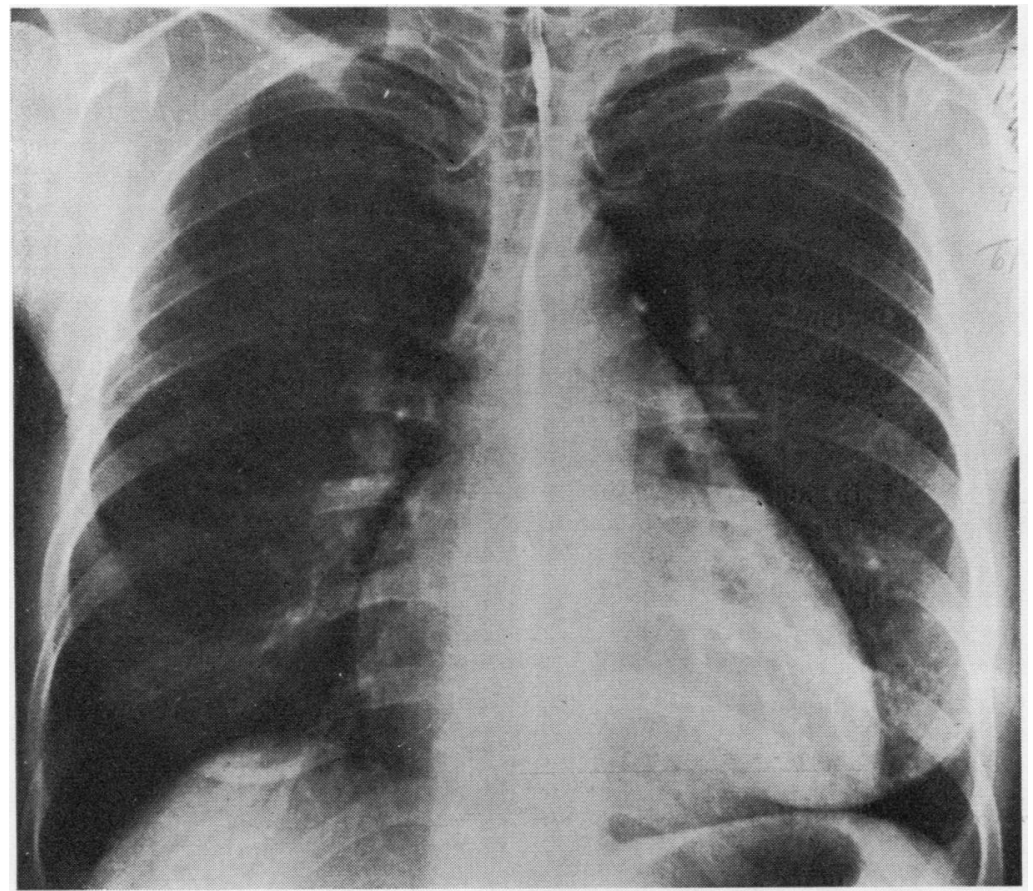

FIG. 1 Case 8. Frontal chest roentgenogram; showing right ventricular enlargement, and no apparent signs of pulmonary fibrosis.

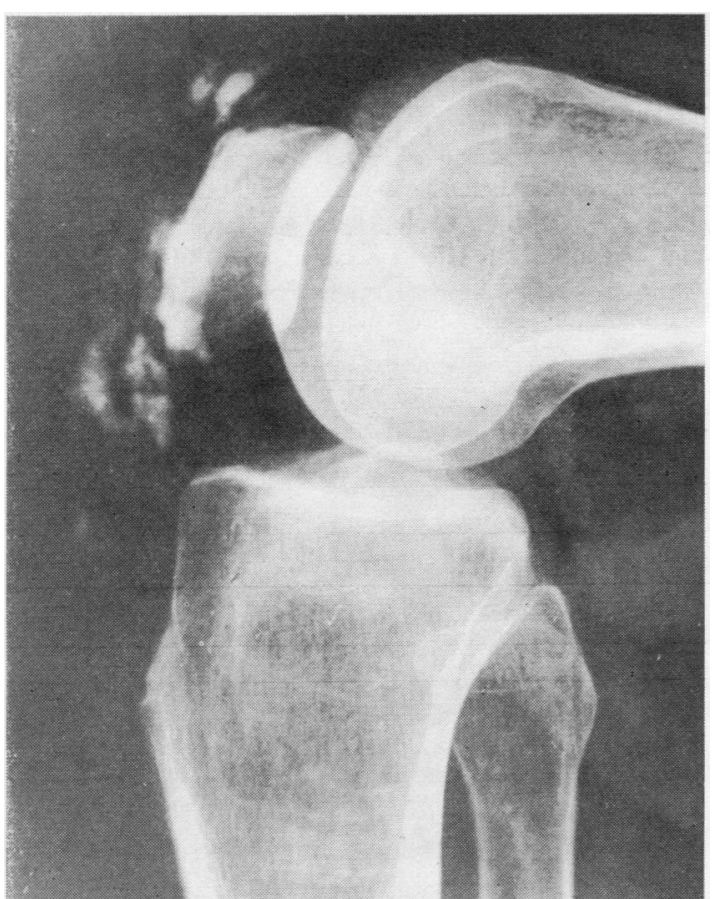

FIG. 2 Case 8. Knee radiograph, showing prepatellar subcutaneous calcifications.

value, TLC 101-109 per cent., FRC 140-154 per cent., RV 144-175 per cent., MVVF 61-64 per cent., FEV $_{1,0}$ 78-81 per cent., $\mathrm{N}_{2}$-time 1.33 min., lung clearance index 7.8-7.3, and Douglas volume 21-23 1 .
Electrocardiograms showed sinus rhythm, right axis deviation, signs of right ventricular hypertrophy and strain, and accentuated and peaked P-waves (Fig. 4, overleaf).

Intracardiac pressure-recordings in September, 1968, revealed a marked pulmonary hypertension of precapillary type (Table I).

Table I Findings in heart catheterization in the reported case

Mean right atrial pressure

$4 \mathrm{~mm} . \mathrm{Hg}$

Systolic right ventricular pressure $86 \mathrm{~mm}$. Hg

Diastolic right ventricular pressure $3-10 \mathrm{~mm}$. Hg

Systolic pulmonary arterial pressure $78 \mathrm{~mm}$. Hg

Mean pulmonary arterial pressure

Mean pulmonary capillary venous pressure

Cardiac output $50 \mathrm{~mm}$. Hg $3 \mathrm{~mm} . \mathrm{Hg}$

$2.51 / \mathrm{min}$.

1,520 dyn. sek. $\mathrm{cm} .^{-5}$

\section{Pathological findings}

The heart was moderately enlarged $(390 \mathrm{~g}$.) with a marked right ventricular hypertrophy (9 mm.) Fig. 5, overleaf). The coronary arteries, myocardium, and heart valves were unremarkable. In the pulmonary artery and its main branches there was a marked atheromatosis (Fig. 6, overleaf), while the pulmonary parenchyma was mainly normal.

There was ascites $(500 \mathrm{ml}$.$) , and the liver (1,355 \mathrm{~g}$. and the spleen had a picture of marked chronic congestion. 
FIG. 4 Electrocardiogram; showFIG. 3 Angiocardiogram (10 sec. after contrast injection); showing $\overrightarrow{\vec{B}}$ right ventricular dilatation and hypertrophy, and slow contrast passage through pulmonary circulation. The central pulmonary arteries are dilated but from the secondary divisions there is a marked narrowing in their calibre. Contrast filling in the peripheral lung fields is very sparse. Case 8. ing sinus rhythm, right axis deviation, and right ventricular hypertrophy and strain. Note accentuated and peaked $P$-waves in leads. V 2-V $3(-V 4)$. Case 8.
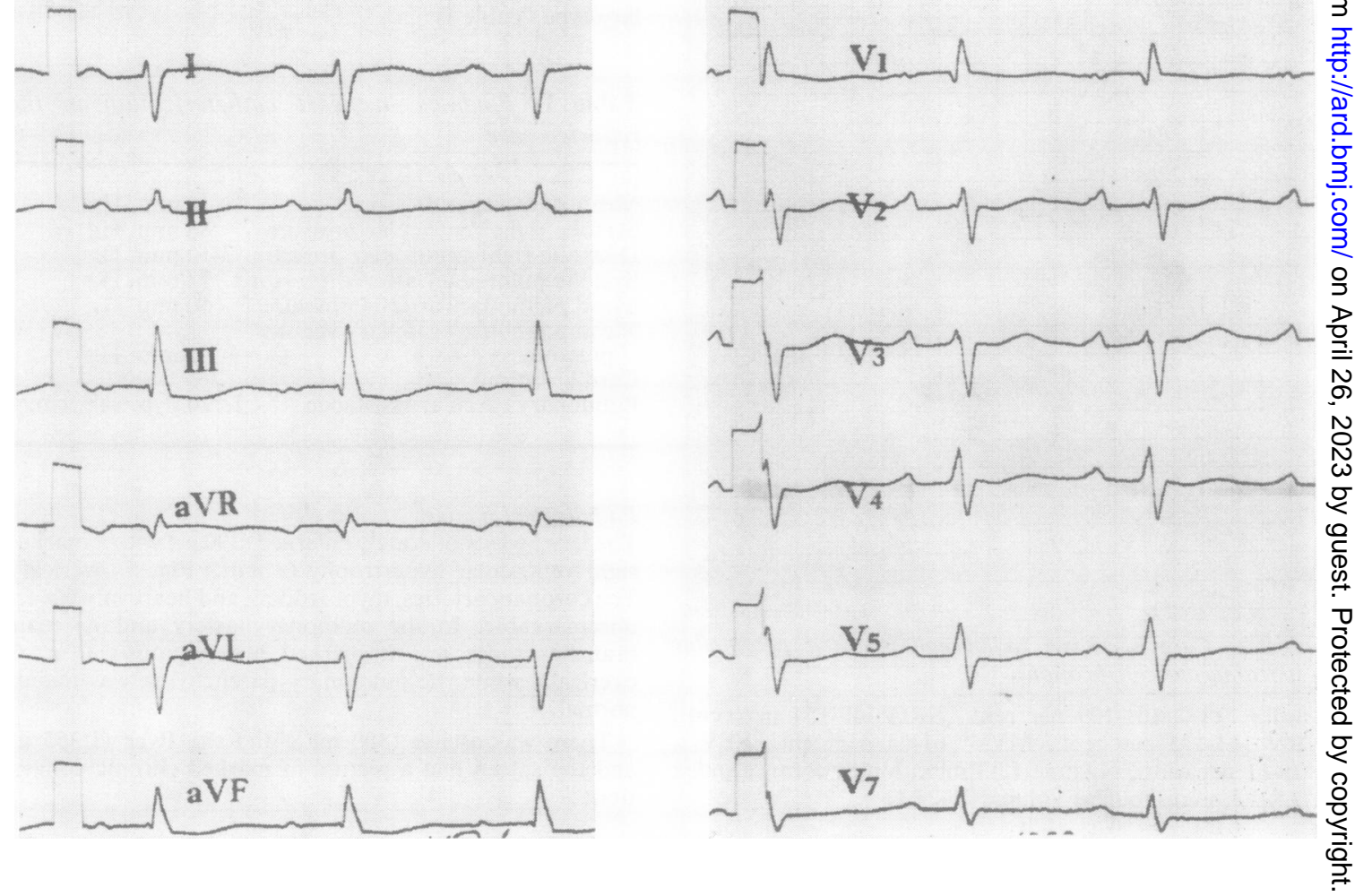


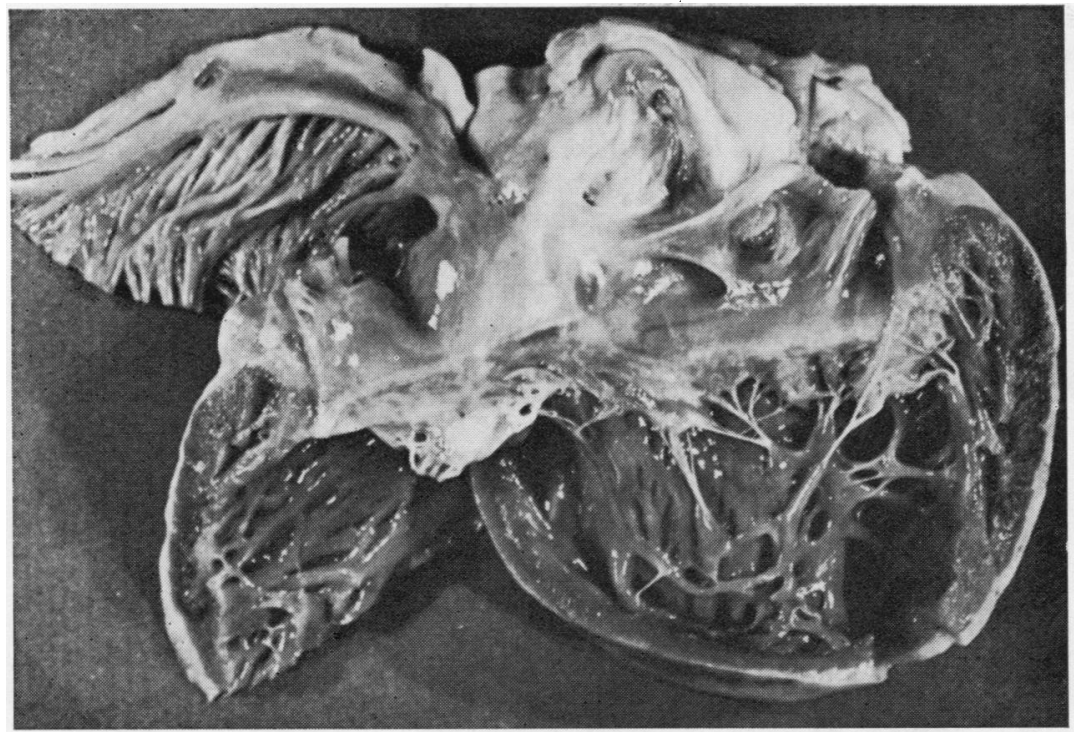

FIG. 5 Right atrium and ventricle of the heart with hypertrophic myocardium, showing dilatation of atrium and ventricle. Case 8.

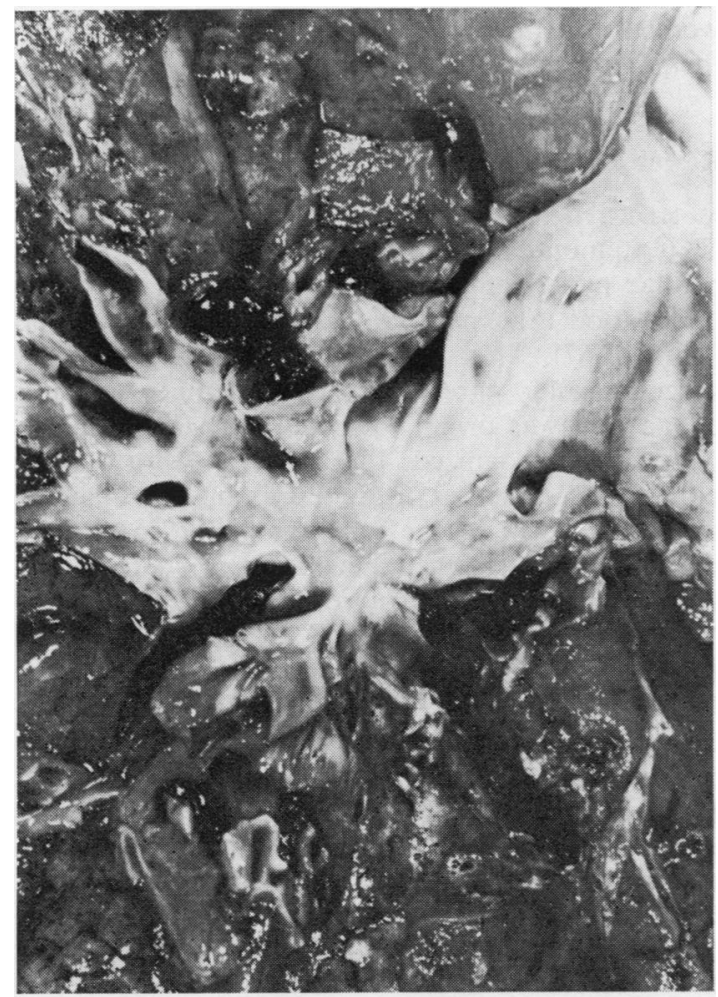

FIG. 6 Main branches of a pulmonary artery with very marked arteriosclerosis. Case 8.

The microscopical examination showed a typical picture of scleroderma in the dermal preparations (Fig. 7). The calcifications of Thibièrge-Weissenbach type had the characteristic picture. There were no signs of fibrosis in

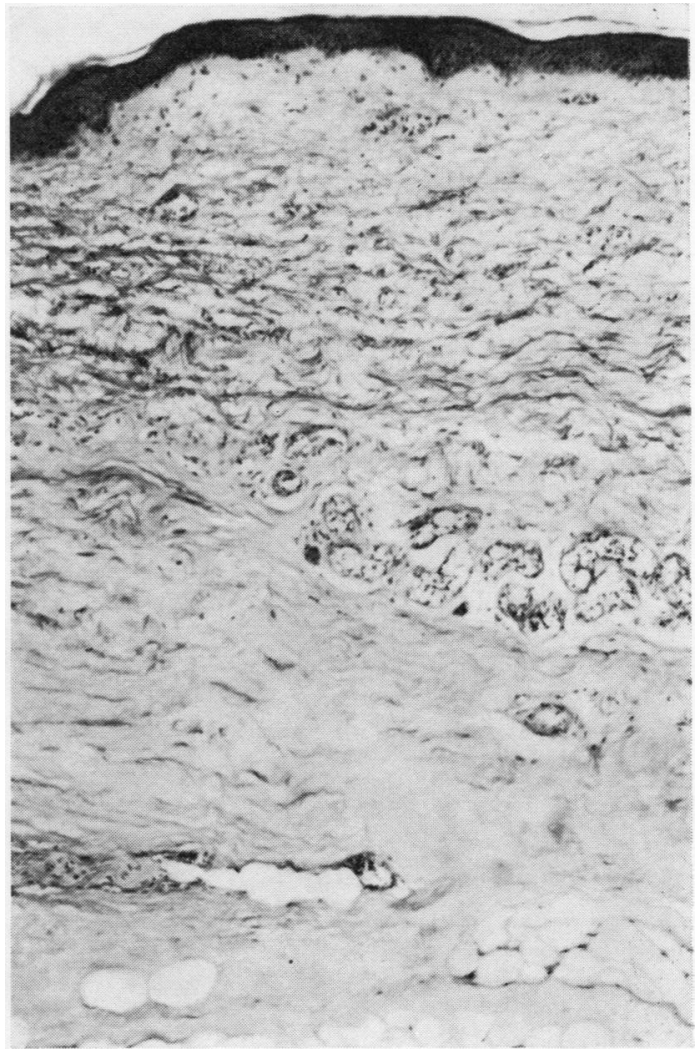

FIG. 7 Histology of skin, showing thin epidermis, collagenization of corium, loss of dermal appendages, and collagenization deep in the subcutis. Case 8.

Haematoxylin and eosin. $\times 75$ 
the lungs, but marked thickening of the walls of the medium-large and small pulmonary arteries and arterioles caused by medial muscular and intimal hyperplasia with very significant reduction of the lumina of the vessels (Figs 8 and 9).

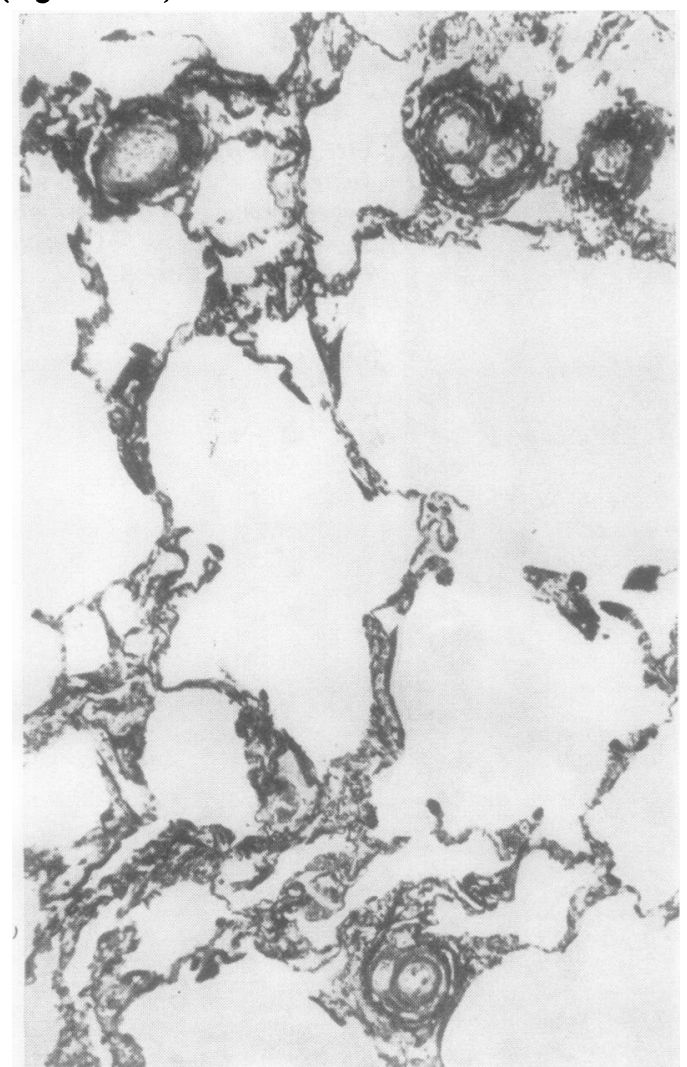

FIG. 8 Lung tissue without fibrosis. There is marked thickening of the walls of the small arteries with very narrow lumina. Case 8. Weigert's elastin. $\times 75$

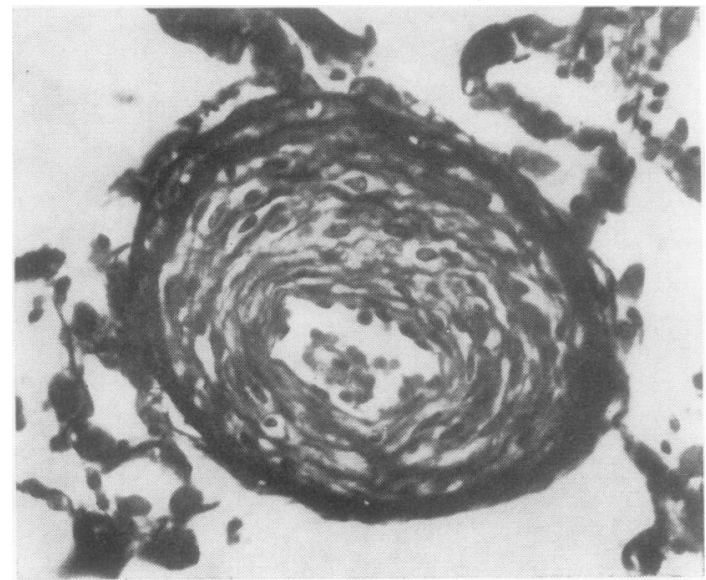

FIG. 9 Small pulmonary artery with very marked intimal and medial hyperplasia. Case 8 . Weigert's elastin. $\times 300$

Preparations from the myocardium, skeletal muscles, and kidneys were mainly normal.
Comparative pathological study of cases of systemic sclerosis

In Malmö, a Swedish town of about 250,000 inhabitants, there is only one large hospital with one pathological institute. About 98.5 per cent. of all deaths at the hospital are submitted to necropsy. From 1957 to 1969 the number of necropsies has been rising from fifty to about 70 per cent. of all $\vec{D}$ deaths in Malmö. During this period ten cases of $\triangle$ systemic sclerosis were necropsied. They were के specially examined in regard to pulmonary fibrosis, $\vec{\circ}$ arteriosclerosis of the pulmonary vessels and heart $\overrightarrow{\vec{H}}$ size. One case had to be omitted because of a diffuse $\vec{\omega}$ cancer in the lungs. The findings in the remaining four men and five women are presented in Table II, ? (opposite), and the extent of pulmonary arterio- 0 sclerosis and pulmonary fibrosis are further summarized in Table III (opposite).

Figures 8 to 15 (overleaf) show examples of different degrees and combinations of these lesions. There appeared to be no strong tendency to a correlation between them. However, all the male $\frac{c}{<}$ subjects had moderate or marked fibrosis, while the women were mainly represented in the lower part of the pulmonary fibrosis scale.

\section{Review of the literature}

A. MORBID ANATOMICAL INVESTIGATIONS

That pulmonary fibrosis can be associated with right cardiac hypertrophy in systemic sclerosis was early understood (Sackner, 1962; Weaver, Divertie, and Titus, 1967). The significance of both pulmonary vascular and parenchymatous changes in this connection was originally noted by Matsui (1924), who also recognized that pleural effusions or adhesions, restriction of the thorax by skin changes, and impairment of the function of the respiratory muscles might disturb the pulmonary circulation. Perivascular inflammatory cell reaction (Masugi and Yä-Shu, 1938; Fischer and Hansen, 1956) and thromboembolism (Masugi and Yä-Shu, 1938; and Naeye, 1963) in the pulmonary arterial bed, pulmonary arteritis with fibrinoid necrosis and inflammation $\mathcal{O}$ (Montgomery, Stirling, and Hamer, 1964; Weaver, N Divertie, and Titus, 1968), and changes in the $N$ pulmonary veins (Naeye, 1963) have been encountered in cases of systemic sclerosis from time to time, but seem to be of little importance. Several investigations of sizeable necropsy series (Naeye, 1963; $\stackrel{\mathbb{D}}{\sim}$ Sackner, Heinz, and Steinberg, 1966; Weaver and others, 1968; D'Angelo, Fries, Masi, and Shulman, 1969) have shown that both pulmonary parenchymatous changes expressed as pulmonary fibrosis (in $\stackrel{\mathbb{D}}{\circ}$ 67-74-100 per cent. of the cases in these series) and pulmonary arterial changes expressed as medial hypertrophy and concentric intimal proliferation in 
Table II Necropsy series of nine patients

\begin{tabular}{|c|c|c|c|c|c|c|c|c|}
\hline \multirow{2}{*}{$\begin{array}{l}\text { Patient } \\
\text { no. }\end{array}$} & \multirow[t]{2}{*}{$\operatorname{Sex}$} & \multirow{2}{*}{$\begin{array}{l}\text { Age } \\
\text { (yrs) }\end{array}$} & \multirow{2}{*}{$\begin{array}{l}\text { Skin } \\
\text { manifestation }\end{array}$} & \multirow[t]{2}{*}{ Lung tissue } & \multirow{2}{*}{$\begin{array}{l}\text { Pulmonary } \\
\text { arteriosclerosis } \\
\text { (atheromatosis } \\
\text { arteriolosclerosis) }\end{array}$} & \multicolumn{2}{|l|}{ Heart } & \multirow{2}{*}{$\begin{array}{l}\text { Other organic } \\
\text { manifestations }\end{array}$} \\
\hline & & & & & & $\begin{array}{l}\text { Weight } \\
(\mathrm{g} .)\end{array}$ & $\begin{array}{l}\text { Thickness of } \\
\text { right ventricular } \\
\text { wall (normal } \\
3-5 \mathrm{~mm} .)\end{array}$ & \\
\hline 1 & $\mathbf{M}$ & 74 & + & $\begin{array}{l}\text { Marked general } \\
\text { and subpleural } \\
\text { fibrosis }(+++)\end{array}$ & Marked $(+++)$ & $\begin{array}{l}640 \text { (including } \\
\text { pericardium) } \\
\text { (left ventricle } \\
\text { hypertrophic) }\end{array}$ & 9 & $\begin{array}{l}\text { Muscles, } \\
\text { oesophagus, } \\
\text { ventricle, } \\
\text { intestines, } \\
\text { pericardium }\end{array}$ \\
\hline 2 & $\mathbf{F}$ & 78 & + & $\begin{array}{l}\text { Slight general } \\
\text { fibrosis }(+)\end{array}$ & Moderate $(++)$ & 510 & 5 & - \\
\hline 3 & $\overline{\mathbf{F}}$ & 65 & $\begin{array}{l}\text { + Thibièrge- } \\
\text { Weissenbach }\end{array}$ & $\begin{array}{l}\text { Marked general } \\
\text { fibrosis }(+++)\end{array}$ & Moderate $(++)$ & 400 & 3 & $\begin{array}{l}\text { Muscle, } \\
\text { oesophagus, } \\
\text { kidneys, } \\
\text { pericardium }\end{array}$ \\
\hline 4 & $\overline{\mathbf{F}}$ & $\overline{56}$ & + & $\begin{array}{l}\text { Slight general } \\
\text { fibrosis }(+)\end{array}$ & Moderate $(++)$ & 400 & 7 & - \\
\hline 5 & $\bar{F}$ & 64 & $\begin{array}{l}\text { + Thibièrge- } \\
\text { Weissenbach }\end{array}$ & $\begin{array}{l}\text { Slight general } \\
\text { fibrosis }(+)\end{array}$ & Slight (+) & $\begin{array}{l}560 \text { (left ventricle } \\
\text { hypertrophic) }\end{array}$ & 5 & Kidneys \\
\hline 6 & $\mathbf{M}$ & 58 & $\bar{t}$ & $\begin{array}{l}\text { Marked general } \\
\text { and subpleural } \\
\text { fibrosis }(t++)\end{array}$ & Moderate $(++)$ & $\overline{340}$ & 5 & - \\
\hline 7 & $\mathbf{M}$ & 70 & + & $\begin{array}{l}\text { Moderate } \\
\text { subpleural } \\
\text { fibrosis }(++)\end{array}$ & Moderate $(++)$ & $\begin{array}{l}560 \text { (left ventricle } \\
\text { hypertrophic) }\end{array}$ & 5 & Kidneys \\
\hline 8 & $\overline{\mathbf{F}}$ & 57 & $\begin{array}{l}\text { + Thibièrge- } \\
\text { Weissenbach }\end{array}$ & No fibrosis (O) & Marked $(+++)$ & 390 & $\overline{9}$ & Oesophagus \\
\hline 9 & $\overline{\mathbf{M}}$ & 71 & + & $\begin{array}{l}\text { Moderate } \\
\text { subpleural } \\
\text { fibrosis }(++)\end{array}$ & Moderate $(++)$ & 310 & 4 & $\begin{array}{l}\text { Kidneys, } \\
\text { oesophagus }\end{array}$ \\
\hline
\end{tabular}

Table III Pulmonary fibrosis and arteriosclerosis in nine necropsy subjects

\begin{tabular}{|c|c|c|c|c|c|}
\hline \multirow{4}{*}{$\begin{array}{l}\text { Pulmonary } \\
\text { fibrosis }\end{array}$} & \multirow{2}{*}{$\frac{\text { Marked }}{\text { Moderate }}$} & & & \multirow{2}{*}{$\frac{2(\text { no. } 3 ; 6)}{2(\text { no. } 7 ; 9)}$} & \multirow[t]{2}{*}{1 (no. 1) } \\
\hline & & & & & \\
\hline & Slight & 1 (no. 5) & & 2 (no. $2 ; 4)$ & \\
\hline & None & & & & 1 (no. 8) \\
\hline \multicolumn{2}{|c|}{$\begin{array}{l}\text { Pulmonary arteriosclerosis: } \\
\text { atheromatosis of pulmonary artery, } \\
\text { hyperplasia of intima and media, } \\
\text { arteriolosclerosis }\end{array}$} & None & Slight & Moderate & Marked \\
\hline
\end{tabular}

the smaller muscular arteries and in the arterioles (29-87-96-100 per cent.) are common in systemic sclerosis. They may co-exist, but seem to be separate and independent manifestations of the disorder. They are both often associated with hypertrophy of the right ventricle; this association is perhaps more significant within pulmonary arterial lesions (Sackner and others, 1966). These findings are reflected also in our series (Tables II and III).
PHYSIOLOGICAL STUDIES

Earlier studies have been reviewed by Sackner (1962) and Weaver and others (1967). In the recent investigation of Sackner, Akgun, Kimbel, and Lewis (1964), it was demonstrated that pulmonary hypertension and lung function values indicative of restrictive and obstructive lung disease might co-exist in systemic sclerosis, but are not infrequently unrelated or isolated. 

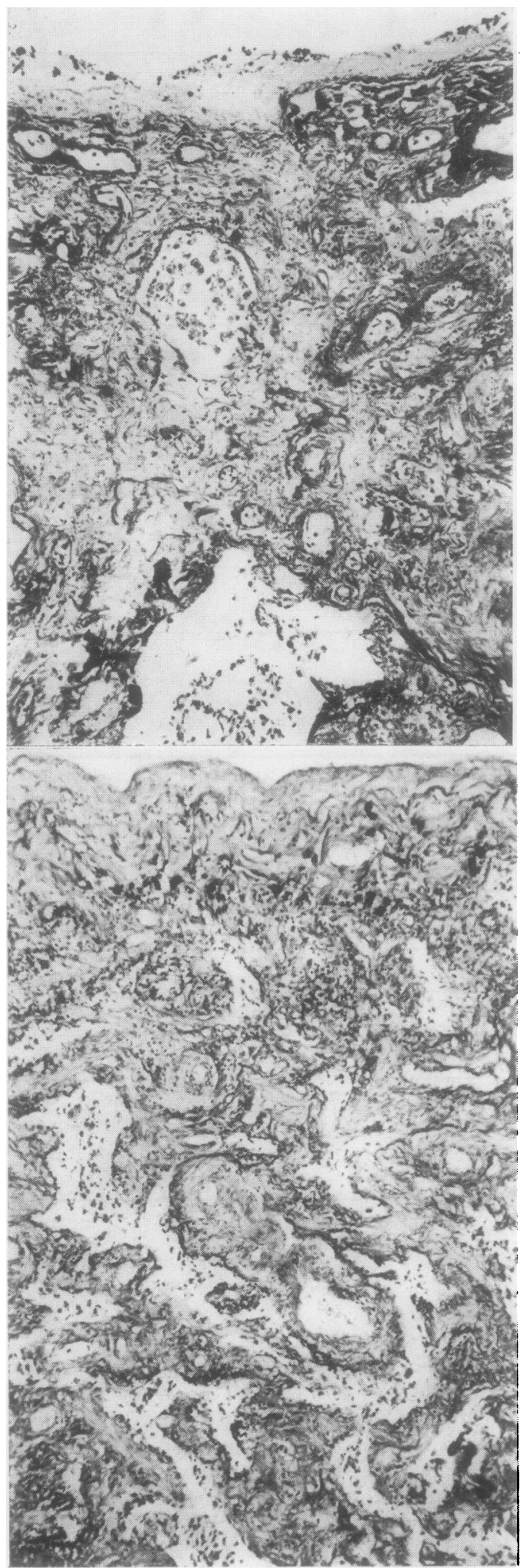

(10)

(11)

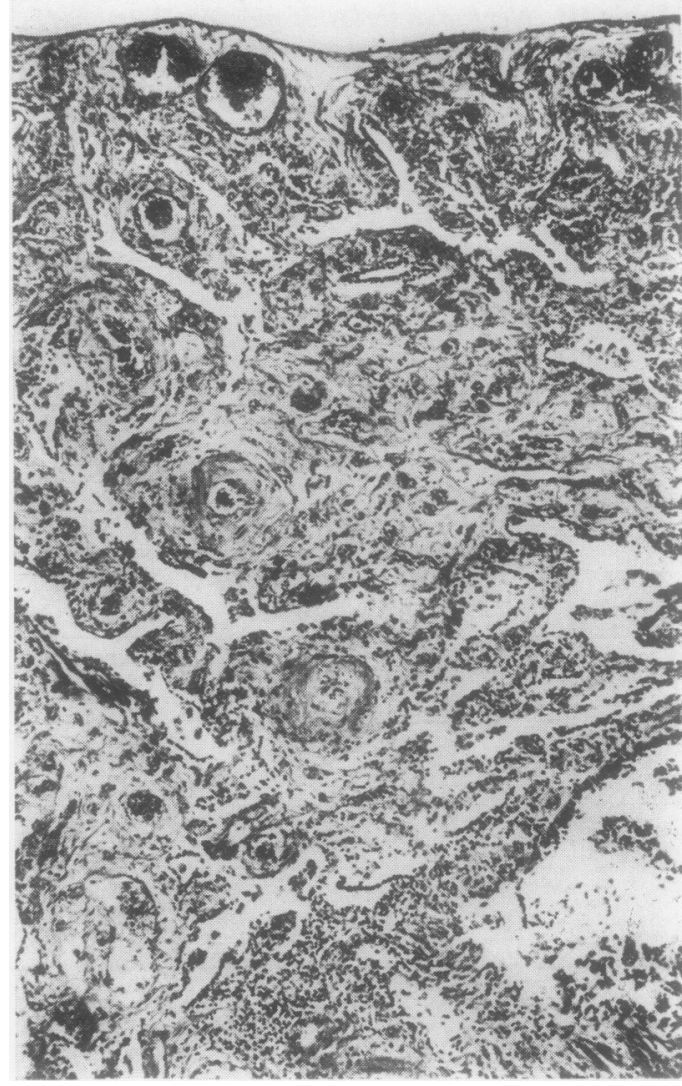

FIG. 10 Case 1. Very marked subpleural fibrosis constricting small vessels.

Weigert's elastin. $\times 75$

옹

FIG. 11 Case 6. Marked fibrosis and moderate vascular N changes.

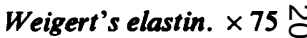

FIG. 12 Case 7. Moderate pulmonary fibrosis and moderate vascular changes.

Weigert's elastin. $\times 75 \stackrel{\frac{0}{D}}{\stackrel{O}{O}}$ 


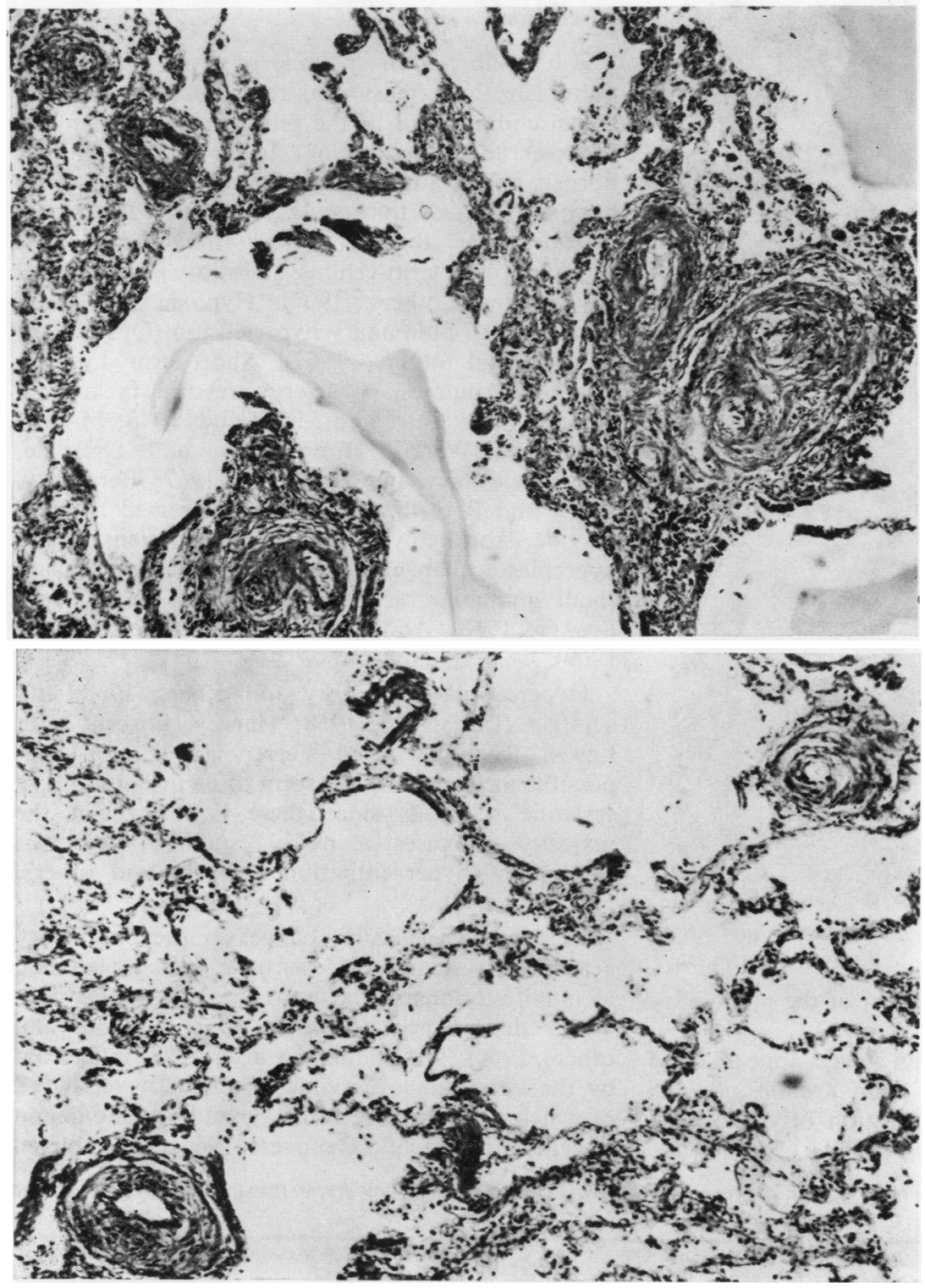

FIGS 13 AND 14 Case 4. Slight pulmonary fibrosis with moderate vascular changes. Weigert's elastin. $\times 75$

\section{CLINICAL DESCRIPTIONS}

An accentuated second pulmonary heart sound in systemic sclerosis was first recognized by HoppeSeyler (1889). Clinical signs of right cardiac hypertrophy were described by Singer (1895) and Lichtwitz (1908) in cases of systemic sclerosis with pulmonary fibrosis. Spain and Thomas (1950) recorded right ventricular hypertension by cardiac catheterization in a similar case. A classical account of pulmonary hypertension in systemic sclerosis is that of Opie (1955). We have found in the literature eleven clinically described cases of systemic sclerosis with pulmonary hypertension verified by heart catheterization: Table IV, overleaf (Spain and Thomas, 1950; Austrian, McClement, Renzetti, Donald, Riley, and Cournand, 1951 ; Foss, 1954; Ellman and Cudkowicz, 1954; Bauer, 1955; Opie, 1955; Fischer and Hansen, 1956; Castleman and Kibbee, 1960; Soulié, Acar, Joly, Carlotti, Bernard, Azérad, and Casillon du Perron, 1961 ; Pace, Decker, and Martin, 1963; Tourniaire, Blum, Tarlulier, and Deyrieux, 1964).

As with the morbid anatomical and physiological studies, three groups may be discerned:

(1) Predominantly lung fibrosis;

(2) Both pulmonary parenchymatous and vascular lesions; 


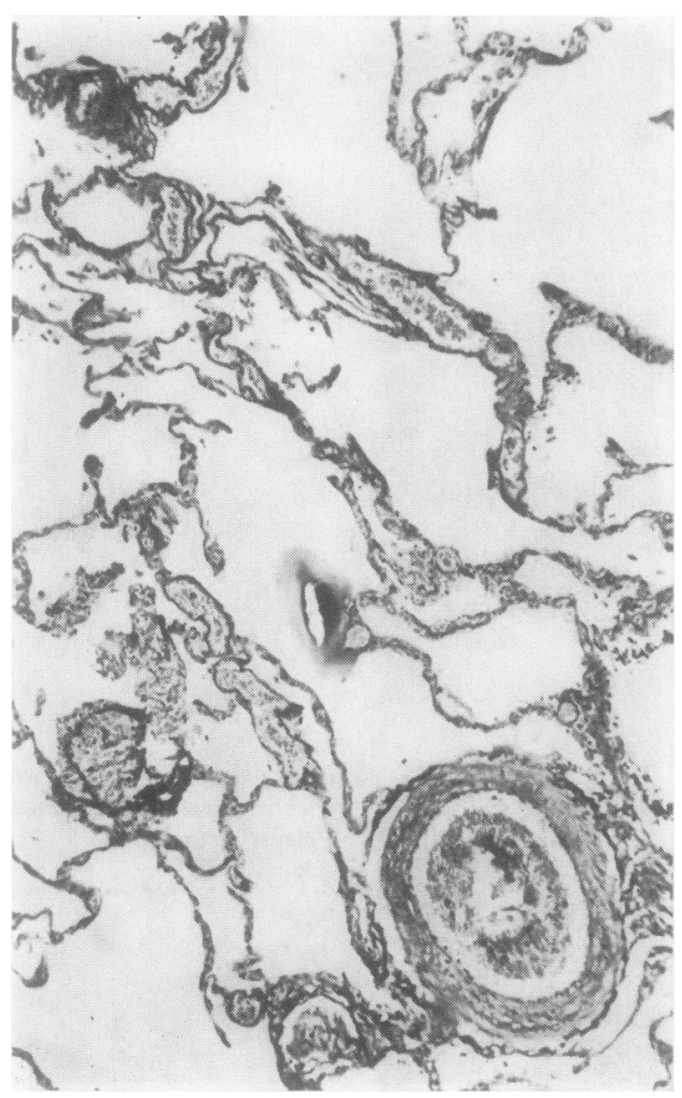

FIG. 15 Case 5. Slight pulmonary fibrosis and slight vascular changes.

Weigert's elastin. $\times 75$

(3) Predominantly involvement of the pulmonary arteries.

The pulmonary hypertension always appears to be of 'precapillary' type, and there are no obvious differences in age, sex, or duration of the disease between the groups.

\section{Discussion}

The lung fibrosis of systemic sclerosis may induce pulmonary hypertension by replacement and mechanical compression of the pulmonary vascular bed (Weaver and others, 1967) and by periadventitial fibrosis and hyalinization. Fibrosis may also cause hypoxia through thickening of the alveolar septa, limitation of the ventilatory movements, and possibly by arterio-venous shunting in the lungs (Weaver and others, 1967). Hypoxia may itself contribute to pulmonary hypertension (Opie, 1955; Weaver and others, 1967). Short-term hypoxia raises the pulmonary artery pressure in normal subjects (Von Euler and Liljestrand, 1946; Motley, Cournand, Werkö, Himmelstein, and Dresdale, 1947; Bergofsky and Holtzman, 1967; Bergofsky, Haas, and Porcelli, 1968), and protracted hypoxia may be associated with pulmonary hypertension and hyperplastic changes in the pulmonary arterioles and small muscular arteries (Hasleton, Heath, and Brewer, 1968; Addington, Pfeffer, and Gaensler, 1969).

Hypercapnia (Bergofsky and others, 1968) and acidosis (Liljestrand, 1958; Harvey, Enson, Betti, Lewis, Rochester, and Ferrer, 1967) are other possible mechanisms, but seem to be insignificant in systemic sclerosis, since there is instead in the majority of cases a mild respiratory alkalosis because of hyperventilation (Weaver and others, 1967).

Primary hyperplastic changes in the pulmonary arteries in systemic sclerosis have been interpreted as manifestations of the common widespread vasomotor disturbances (Sackner, 1962; Sackner and others, 1964). The pulmonary arteries are influenced by the sympathetic nervous system, "overactivity" of which is also inferred in Raynaud's phenomenon (Rogge, Mishkin, and Genovese, 1966). A protracted

Table IV Summary of reports of cases of systemic sclerosis with pulmonary hypertension verified by heart catheterization

\begin{tabular}{|c|c|c|c|c|c|c|c|c|c|c|}
\hline \multirow[t]{3}{*}{ Author } & \multirow[t]{3}{*}{ Year } & \multirow{2}{*}{\multicolumn{2}{|c|}{$\frac{\text { Patients }}{\text { Sex Age }}$}} & \multicolumn{3}{|l|}{ Pressures } & \multirow{3}{*}{$\begin{array}{l}\text { Pulmonary } \\
\text { vascular } \\
\text { resistance }\end{array}$} & \multirow{3}{*}{$\begin{array}{l}\text { Chest } x \text { ray } \\
\text { or } \\
\text { Necropsy }\end{array}$} & \multirow{3}{*}{$\begin{array}{l}\text { Pulmonary } \\
\text { fibrosis }\end{array}$} & \multirow{3}{*}{$\begin{array}{l}\text { Pulmonary } \\
\text { arterio- } \\
\text { sclerosis }\end{array}$} \\
\hline & & & & \multicolumn{2}{|c|}{ Pulmonary artery } & \multirow{2}{*}{$\begin{array}{l}\begin{array}{l}\text { Pulmonary } \\
\text { capillary } \\
\text { venous }\end{array} \\
\text { Mean }\end{array}$} & & & & \\
\hline & & & & Systolic & Mean & & & & & \\
\hline A. Spain and Thomas & 1950 & $\mathbf{M}$ & 65 & 71 & - & - & - & Necropsy & Yes & No \\
\hline $\begin{array}{l}\text { B. Austrian and others } \\
\text { C. Foss } \\
\text { D. Ellman and Cudkowicz } \\
\text { E. Opie } \\
\text { F. Soulié and others }\end{array}$ & $\begin{array}{l}1951 \\
1954 \\
1954 \\
1955 \\
1961\end{array}$ & $\begin{array}{l}\mathbf{F} \\
\mathbf{F} \\
\mathbf{M} \\
\mathbf{M}\end{array}$ & $\begin{array}{l}22 \\
53 \\
66 \\
50 \\
49\end{array}$ & $\begin{array}{l}\frac{32}{50} \\
\frac{5}{50}\end{array}$ & $\begin{array}{l}20 \\
32 \\
47 \\
27\end{array}$ & $\frac{\overline{5}}{12}$ & $\begin{array}{l}\overline{365} \\
\overline{520}\end{array}$ & $\begin{array}{l}\text { Chest } x \text { ray } \\
\text { Chest } x \text { ray } \\
\text { Chest } x \text { ray } \\
\text { Necropsy } \\
\text { Chest } x \text { ray }\end{array}$ & $\begin{array}{l}\text { Yes } \\
\text { Yes } \\
\text { Yes } \\
\text { Yes } \\
\text { Yes }\end{array}$ & $\bar{z}$ \\
\hline $\begin{array}{l}\text { G. Bauer } \\
\text { H. Tourniaire and others }\end{array}$ & $\begin{array}{l}1954 \\
1964\end{array}$ & $\overline{\mathbf{M}}$ & $\begin{array}{l}50 \\
60\end{array}$ & $\begin{array}{l}45 \\
75\end{array}$ & $\begin{array}{l}30 \\
41\end{array}$ & $\overline{0}$ & $\overline{970}$ & $\begin{array}{l}\text { Necropsy } \\
\text { (Biopsy) }\end{array}$ & $\begin{array}{l}\text { Yes } \\
\text { Yes }\end{array}$ & $\begin{array}{l}Y e s \\
Y \in s\end{array}$ \\
\hline $\begin{array}{l}\text { I. Fischer and Hansen } \\
\text { J. Castleman and Kibbee } \\
\text { K. Pace and others }\end{array}$ & $\begin{array}{l}1956 \\
1960 \\
1963\end{array}$ & $\begin{array}{l}\mathbf{F} \\
\mathbf{F}\end{array}$ & $\begin{array}{l}30 \\
64 \\
37\end{array}$ & $\begin{array}{l}60 \\
60 \\
100\end{array}$ & $\begin{array}{l}\overline{36} \\
50\end{array}$ & $\begin{array}{l}5 \\
6 \\
11\end{array}$ & $\overline{460}$ & $\begin{array}{l}\text { Necropsy } \\
\text { Necropsy } \\
\text { Chest } x \text { ray }\end{array}$ & $\begin{array}{l}\text { No } \\
\text { No } \\
\text { No. }\end{array}$ & $\dot{q}^{\mathbf{Y} e s}$ \\
\hline
\end{tabular}

Notes: Pressure values are given in $\mathrm{mm}$. Hg, and pulmonary vascular resistance in dyn $\times$ sek $\times \mathrm{cm}^{6}$.

The term 'pulmonary arteriosclerosis' also includes hyperplastic changes in smaller pulmonary arterial ramifications (hyperplasia of intime and media, and arteriolosclerosis). Cases $\mathrm{B}, \mathrm{C}, \mathrm{D}, \mathrm{F}$, and $\mathrm{K}$ were investigated by chest $x$-ray only, and no conclusions could be drawn. In Case I the description was insufficiently detailed. 
3pasm in the smaller pulmonary arteries may induce irreversible lumen-reducing changes of medial hypertrophy and intimal proliferation in their walls (Short, 1957; Celoria, Friedell, and Sommers, 1960; Downing, Bidone, Brandt, and Liebow, 1963; Boiteau and Libanoff, 1963; Hasleton and others, 1968). However, the major effects in the lesser ariculation of (short-term) sympathetic nerve stimulation seem to be exerted on the larger pulmonary rcteries rather than on the smaller, and cause little change in pulmonary vascular resistance (Ingram, Szidon, Skalak, and Fishman, 1968). Another possibility is that the sympathetic "overactivity" in the smaller pulmonary arteries reflects a local rather than a central disturbance. At least in capillary basal membranes, swelling and other pathological changes are a regular feature of systemic sclerosis (Norton, Hurd, Lewes, and Zift, 1968; Norton and Nardo, 1970). It seems possible that pulmonary arterial vasoconstriction may be secondary to a local sclerodermatous involvement which disturbs, for instance by inflammatory or degenerative action, the function of the active electrolyte transport system of the cell membrane in the pulmonary arterial smooth muscle, so that the resting negative intracellular potential moves closer to zero and to the threshold for the production of action potentials and active contraction. Recent data suggest that, in such a situation, a vasoconstriction will occur in the pulmonary vasculature (Bergofsky and Holtzman, 1967).

Pulmonary hypertension has exceptionally been reported in collagenoses other than systemic sclerosis (Ellman and Cudlowicz, 1954; Caldwell and Aitchison, 1956; Sullivan and Miller, 1962; Pace and others, 1963; Onodera and Hill, 1965), but in systemic sclerosis a disturbance of the pulmonary circulation appears to be a regular rather than an exceptional development in the long perspective of the disorder. Our case may still be a rare extreme in the variability of possible combinations and degrees of different pulmonary lesions in systemic sclerosis. By the dominant arterial involvement it resembles reported cases of 'Primary pulmonary hypertension and Raynaud's phenomenon', most of them females, and some actually representing typical systemic sclerosis (Winters, Joseph, and Learner, 1964). Even cases without skin changes may fall within the systemic sclerosis symptom complex (Sackner and others, 1964). This would seem to be a clue to the aetiology of 'primary' pulmonary hypertension, but primary pulmonary hypertension is not a uniform disease. For instance, familial occurrence (which in itself does not rule out a collagenous nature (Rogge and others, 1966; and Burge, Perry, and Stickler, 1969)) has been described (see Boiteau and Libanoff, 1963; Rogge and others, 1966), and such cases usually differ in clinical and morbid anatomical respects from 'primary pulmonary hypertension and Reynaud's phenomenon'.

\section{Summary}

A case is reported of a 57-year-old woman with systemic sclerosis, who developed a severe pulmonary hypertension and rapidly progressive right heart failure attributable to hyperplastic changes in the smaller pulmonary arteries and arterioles. A retrospective investigation of pulmonary lesions in a necropsy series of cases of systemic sclerosis showed that both lung fibrosis and hyperplastic changes in the pulmonary arteries are common in the disorder, that they may be independant of each other, and that both may be associated with right cardiac hypertrophy. This is in accordance with the findings in earlier morbid anatomical, physiological, and clinical studies concerning cor pulmonale and pulmonary hypertension in systemic sclerosis, which are reviewed. Some possible mechanisms of pulmonary hypertension in systemic sclerosis and the relationship of the reported case to various types of 'primary pulmonary hypertension' are discussed.

\section{References}

Addington, W. W., Pfeffer, S. H., and Gaensler, E. A. (1969) Respiration, 26,214 (Obesity and alveolar hyperventilation).

Austrian, R., McClement, J. H., Renzetti, A. D., Jr., Donald, K. W., Riley, R. L., ANd CouRnand, A. (1951) Amer. J. Med., 11, 667 (Clinical and physiologic features of some types of pulmonary diseases with impairment of alveolar-capillary diffusion).

Bauer, G. E. (1955) Austr. Ann. Med., 4, 149 (Scleroderma with heart failure).

Bergofsky, E. H., HaAs, F., and Porcelli, R. (1968) Fed. Proc., 27, 1420 (Determination of the sensitive vascular sites from which hypoxia and hypercapnia elicit rises in pulmonary arterial pressure).

- AND Holtzman, S. (1967) Circulat. Res., 20, 505 (A study of the machanisms involved in the pulmonary arterial pressor response to hypoxia).

Borteau, G. M., AND Libanoff, A. J. (1963) Angiology, 14, 260 (Primary pulmonary hypertension: familial incidence).

Burge, K. M., Perry, H. O., And Stickler, G. B. (1969) Arch. Derm., 99, 681 ('Familial' scleroderma).

Caldwell, I. W., AND Aitchison, J. D. (1956) Brit. Heart J., 18, 273 (Pulmonary hypertension in dermatomyositis). 
Castleman, B., And Kibbee, B. U. (1960) New Engl.J. Med., 262, 981 (Case records of the Massachusetts General Hospital. Weekly clinico-pathological exercises. Case 46191).

Celoria, G. C., Friedell, G. H., AND Sommers, S. C. (1960) Circulation, 22, 1055 (Raynaud's disease and primary pulmonary hypertension).

D'Angelo, W. A., Fries, J. F., Masi, A. T., and Shulman, L. E. (1969) Amer. J. Med., 46, 428 (Pathologic observations in systemic sclerosis (scleroderma). A study of 58 autopsy cases and 58 matched controls).

Downing, S. E., Vidone, R. A., Brandt, H. M., And Liebow, A. A. (1963) Amer. J. Path., 43, 739 (The pathogenesis of vascular lesions in experimental hyperkinetic pulmonary hypertension).

Ellman, P., AND CudKowicz, L. (1954) Thorax, 9, 46 (Pulmonary manifestations in the diffuse collagen diseases).

Euler, von, U. S., AND LiLJESTRAND, G. (1946) Acta physiol. scand., 12, 301 (Observations on the pulmonary arterial blood pressure in the cat).

FisChER, S., AND HANSEN, P. F. (1956) Nord. Med., 56, 1283 (Diffus myocarditis i indledende stadium af sclerodermi).

Foss, P. O. (1954) Ibid., 52, 917 (Sclerodermi med lungefibrose).

Harvey, R. M., Enson, Y., Betti, R., Lewis, M. L., Rochester, D. F., AND Ferrer, M. I. (1967) Circulation, 35, 1019 (Further observations on the effect of hydrogen ion on the pulmonary circulation).

Hasleton, P. S., Heath, D., AND BreWER, D. B. (1968) J. Path. Bact., 95, 431 (Hypertensive pulmonary vascular disease in states of chronic hypoxia).

HopPe-Seyler, G. (1889) Dtsch. Arch. klin. Med., 44, 581 (Zwei Fälle von Sklerodermie).

Ingram, R. H., Szidon, J. P., Skalak, R., And Fishman, A. P. (1968) Circulat. Res., 22, 801 (Effects of sympathetic nerve stimulation on the pulmonary arterial tree of isolated lobe perfused in situ).

LichrwITZ, L. (1908) Dtsch. Arch. klin. Med., 94, 567 (Über einen Fall von Sklerodermie und Morbus Addisonii nebst Bemerkungen über die Physiologie und Pathologie des Sympathicus und der Nebennieren).

LILJESTRAND, G. (1958) Acta physiol. scand., 44, 216 (Chemical control of the distribution of the pulmonary blood flow).

MASUGI, M., AND Yä-Shu (1938) Virchows Arch. path. Anat., 302, 39-62 (Die diffuse Sklerodermie und ihre Gefässveränderung).

MatsuI, S. (1924) Mitt. med. Fak. kais. Univ., Tokyo, 31, 55 (Über die Pathologie und Pathogenese von Sclerodermia universalis).

Montgomery, R. D., StiRling, G. A., AND Hamer, N. A. J. (1964) Lancet, 1, 586 (Bronchiolar carcinoma in progressive systemic sclerosis).

Motley, H. L., Cournand, A., Werkö, L., Himmelstein, A., And Dresdale, D. (1947) Amer. J. Physiol., 150,315 (The influence of short periods of induced acute anoxia upon pulmonary artery pressures in man).

NaEYe, R. L. (1963) Dis. Chest, 44, 374 (Pulmonary vascular lesions in systemic scleroderma).

NorTon, W. L., HURD, E. R., LEWIS, D. C., AND ZIFF, M. (1968) J. Lab. clin. Med., 71, 919 (Evidence of microvascular injury in scleroderma and systemic lupus erythematosus: Quantitative study of the microvascular bed).

— AND NARDO, J. M. (1970) Ann. intern. Med., 73, 317 (Vascular disease in progressive systemic sclerosis (scleroderma)).

ONODERA, S., AND Hill, J. R. (1965) Ohio med. J., 61, 141 (Pulmonary hypertension. Report of a case in association with rheumatoid arthritis).

OPIE, L. H. (1955) Dis. Chest, 28, 665 (Pulmonary manifestations of generalised scleroderma (Progressive systemic sclerosis)).

Pace, W. R., Jr., Decker, J. L., AND Martin, C. J. (1963) Amer. J. med. Sci., 245, 322 (Polymyositis: Report of two cases with pulmonary function studies suggestive of progressive systemic sclerosis).

RogGe, J. D., Mishin, M. E., AND Genovese, P. D. (1966) Ann. intern. Med., 65, 672 (Familial occurrence of primary pulmonary hypertension).

SACKNER, M. A. (1962) Arthr. and Rheum., 5, 184 (Visceral manifestations of scleroderma).

—, Akgun, N., KImBel, P., AND LeWIS, D. H. (1964) Ann. intern. Med., 60, 611 (The pathophysiology of Scleroderma involving the heart and respiratory system).

- Heinz, E. R., ANd Steinberg, A. J. (1966) Amer. J. Cardiol., 17, 542 (The heart in scleroderma).

SHORT, D. S. (1957) Lancet, 2, 12 (The arterial bed of the lung in pulmonary hypertension).

SINGER, G. (1895) Berl. klin. Wschr., 32, 226-229 (II. Zur Pathologie der Sklerodermie).

Soulié, P., Acar, J., Joly, F., Carlotti, J., Bernard, C., Azérad, N., and Casillon du Perron, M. (1961) Mal. cardiovasc., 2, 329 (Le poumon sclérodermique. Ses manifestations cardiaques).

Spain, D. M., AND ThOMAS, A. G. (1950) Ann. intern. Med., 32, 152 (The pulmonary manifestations of Scleroderma: an anatomical-physiological correlation).

Sullivan, M. A., AND Miller, D. K. (1962) Arch. intern. Med., 110, 769 (Pulmonary manifestations in collagen disease).

Tourniaire, A., Blum, J., Tartulier, M., And Deyrieux, F. (1964) Presse méd., 72, 2269 (Coeur pulmonaire chronique sclérodermique).

Weaver, A. L., Divertie, M. B., ANd Titus, J. L. (1968) Dis. Chest, 54, 490 (Pulmonary scleroderma). (1967) Mayo Clin. Proc., 42, 754 (The lung in scleroderma).

Winters, W. L., Jr., JosePH, R. R., AND LEARNER, N. (1964) Arch. intern. Med., 114, 821 ('Primary' pulmonary hypertension and Raynaud's phenomenon. Case report and review of the literature). 